\title{
A relation between the energy of food and gastric emptying in men with duodenal ulcer
}

\author{
D. F. STUBBS AND J. N. HUNT \\ From the Department of Physiology, Guy's Hospital Medical School, London
}

SUMMARY Using information about the volume and energy density of meals, results from the literature on gastric emptying for healthy men can be marshalled into a consistent body. The same process applied to the published papers on men with duodenal ulcer shows that they have abnormally rapid gastric emptying, especially for meals of high-energy density. This provides confirmation of the view of Shay (1944) that the slowing of gastric emptying by duodenal receptors is less in men with duodenal ulcer than it is in healthy men.

It has been found that the greater the energy density of food $(\mathrm{Kcal} / \mathrm{ml})$ the slower is the rate at which the food leaves the stomach (Hunt and Stubbs, 1975).

The relationship (1) was based on 25 studies from seven different laboratories in over 250 healthy men. From the energy density of a meal and its volume, the time for the first half of a meal to pass from the stomach to the duodenum can be predicted. The link between the energy density of food and the rate of gastric emptying is believed to depend upon duodenal receptors responding to the products of hydrolysis of carbohydrates and of protein, and to the soaps formed during the digestion of fat.

In the present paper we list the half times of gastric emptying of a variety of meals given to men with duodenal ulcer and compare the rates with those predicted for healthy men, had they been given the same meals.

\section{Methods}

The energy density of the food or test solutions was based on $4 \mathrm{Kcal} / \mathrm{g}$ of carbohydrate and/or protein per $\mathrm{ml}$ of meal and $9 \mathrm{Kcal} / \mathrm{g}$ of fat per $\mathrm{ml}$ of meal. The values for energy density were substituted in the relation found by Hunt and Stubbs (1975):

$$
\begin{aligned}
& t_{0.5}=V_{0}\left[0 \cdot 1797-0.1670 \mathrm{e}^{-\mathrm{K}}\right] \cdot . \cdot . \cdot \dot{A}^{(1)} \\
& \text { where } t_{0.5}=\text { measured time to empty the first } \\
& \text { half of the meal [min] }
\end{aligned}
$$

Received for publication 17 June 1975.

$$
\begin{aligned}
& \mathbf{K}=\mathbf{K c a l} / \mathrm{ml} \text { meal } \\
& {\left[\mathbf{e}^{-\mathbf{K}} \begin{array}{l}
\text { was obtained from mathematical } \\
\text { tables }]
\end{array}\right.} \\
& \mathrm{V}_{0}=\text { volume of meal given [ml] }
\end{aligned}
$$

The value $t_{0.5}$ is literally the time to empty the first half of the meal and does not necessarily imply any particular pattern of emptying.

\section{Results}

The table shows the data taken from nine sources. It can be seen that the greater the energy density of the meal, progressing down the table, the shorter are the observed half times of the patients with duodenal ulcer relative to those computed for healthy persons. At zero calories the difference between the two groups is not significant.

\section{Discussion}

Relation (1) based on results for 250 healthy men, gives predictions about half times of gastric emptying from initial volumes of meals and their energy densities. Apart from meals of water, the values for men with duodenal ulcer show shorter times for emptying than those predicted for the healthy men. This confirms the view of the majority of the authors quoted. This conclusion is more apparent with meals of high-energy density (see table). Thus in men with duodenal ulcer gastric emptying is slowed less than 


\begin{tabular}{|c|c|c|c|c|c|c|}
\hline$K[k c a l / m l]$ & $V_{0}[m l]$ & $\begin{array}{l}\text { Measured } t_{0.5}[\mathrm{~min}] \\
\text { (Patients) }\end{array}$ & $\begin{array}{l}\text { Calculated } t_{0.8} \\
\text { (Normals) }\end{array}$ & $\begin{array}{l}\text { Differences } D \\
\text { (min) }\end{array}$ & Source (and Number of Subjects) & \\
\hline $\begin{array}{l}0.00 \\
0 \cdot 36 \\
0 \cdot 36 \\
1 \cdot 00 \\
1.00 \\
1.00 \\
1 \cdot 16 \\
1.34 \\
2 \cdot 30\end{array}$ & $\begin{array}{l}750 \\
400 \\
750 \\
300 \\
550 \\
300 \\
300 \\
290 \\
350\end{array}$ & $\begin{array}{l}14 \cdot 8 \\
21 \cdot 2 \\
38 \cdot 9 \\
22 \cdot 7 \\
55 \cdot 2 \\
26 \cdot 2 \\
22 \cdot 4 \\
31 \cdot 0 \\
30 \cdot 4\end{array}$ & $\begin{array}{l}13 \cdot 0 \\
25 \cdot 3 \\
47 \cdot 4 \\
35 \cdot 5 \\
65 \cdot 0 \\
35 \cdot 5 \\
38 \cdot 2 \\
39 \cdot 4 \\
57 \cdot 0\end{array}$ & $\begin{array}{l}-1 \cdot 8 \\
+4 \cdot 1 \\
+8 \cdot 5 \\
+12 \cdot 8 \\
+9 \cdot 8 \\
+9 \cdot 3 \\
+15 \cdot 8 \\
+8.4 \\
+26.6\end{array}$ & $\begin{array}{l}\text { Cobb et al (1971) } \\
\text { Donovan (1974) } \\
\text { Hunt (1957) } \\
\text { Humphrey et al (1972) } \\
\text { Griffith et al (1968) } \\
\text { Moberg et al (1972) } \\
\text { Moberg and Carlberger (1973) } \\
\text { Bromster (1969) } \\
\text { Harvey et al (1970) }\end{array}$ & $\begin{array}{l}(12) \\
(12) \\
(16) \\
(15) \\
(27) \\
(16) \\
(6) \\
(15) \\
(5)\end{array}$ \\
\hline
\end{tabular}

Table Gastric emptying in male patients ${ }^{1}$ with duodenal ulcers

${ }^{1} \mathrm{~K}=$ Calorie density of meal $(\mathrm{kcal} / \mathrm{ml}) ; \mathrm{V}_{0}=$ initial volume of meal $(\mathrm{ml}) ; \mathrm{t}_{0.5}=$ half-time of meal $(\mathrm{min}) ;(1 \mathrm{Kcal}=4 \cdot 18 \mathrm{Ki})$. $t_{0.5}$ (Patients) was abstracted or derived from papers cited; $t_{n \cdot s}$ (normals) was calculated from $t_{0.8}=V_{0}\left(0.1797-0.1670 e^{-K}\right)$ (Hunt and Stubbs, 1975): $D=t_{0.5}$ (normals) $-t_{0 . s}$ (patients). A regression analysis of $D$ upon $K$ gives: $D=0.2853+10.6727 K(S E($ Intercept) + 2.6222; SE (slope) + 1.7996)

it would be by an equivalent stimulus in healthy men.

Gastric emptying can be influenced by the interaction of nerves and hormones on smooth muscle. These nerves and hormones may also have effects on metabolism. Since patients with duodenal ulcer may be expected to have inflammatory damage of the duodenal mucosa, they may also have abnormal release by food of hormones controlling metabolism. The low fasting serum lipids (Zuber and WozniakZuber, 1967) and the high serum insulin following oral glucose (Buchanan, McKiddie, Lindsay, and Manderson, 1967) in duodenal ulcer patients are interesting in this context.

\section{References}

Brömster, D. (1969). Gastric emptying rate in gastric and duodenal ulceration: a clinical study including the changes of the gastric contents after a liquid test meal. Scand. J. Gastronterol., 4, 193-201.

Buchanan, K. D., McKiddie, M. T., Lindsay, A. C., and Manderson, W. G. (1967). Carbohydrate metabolism in duodenal ulcer patients. Gut, 8, 325-331.
Cobb, J. S., Bank, S., Mark, I. N., and Louw, J. H. (1971). Gastric emptying after vagotomy and pyloroplasty. Amer. J. dig. dis. 16, 207-215

Donovan I. (1974). Personal communication.

Griffith, G. H., Owen, G. M., Campbell, P. H., and Shields, R. (1968). Gastric emptying in health and in gastroduodenal disease. Gastroenterology, 54, 1-7.

Humphrey, C. S., Wilkinson, A. R., and Johnston, D. (1972). The correlation between the rate of gastric emptying and dumping and diarrhoea after truncal, selective and highly selective vagotomy. Brit. J. Surg., 59, 309.

Hunt, J. N. (1957). Inhibition of gastric emptying and secretion in patients with duodenal ulcer. Lancet, 1, 132-134.

Hunt, J. N. and Stubbs, D. F. (1975). The volume and energy content of meals as determinants of gastric emptying. J. Physiol. (Lond.), 245, 209-225.

Harvey, R. F., Mackie, D. B., Brown, N. J. G., Keeling, D. H., and Davies, W. T. (1970). Measurements of gastric emptying time with a gamma camera. Lancet, 1, 16-18.

Moberg, S., and Carlberger, G. (1973). Gastric emptying after selective proximal vagotomy in relation to the outcome of the insulin test. R.C. Gastroent., 5, 163-167.

Moberg, S., Carlberger, G., Básány, F., and Lundh, G. (1972). Gastric emptying in peptic ulcer patients before and after. partial gastrectomy and selective proximal vagotomy. R.C. Gastroent., 4, 1-7.

Shay, H. (1944). The pathologic physiology of gastric and duodenal ulcer. Bull. N.Y. Acad. Med., 20, 264-291.

Zuber, E., and Wozniak-Zuber, H. (1967). Zawartosc lipidow calkowitych, cholestrolu i beta-lipoprotein $w$ surowicy krwi w niektorych chorobach przewodu pokarmowego. Pol. Tyg. Lek, 22, 872-3. 